\title{
Radiometric Evaluation in a Uranium Mine under a Decommisioning Processs
}

\author{
Vinícius Verna Magalhães Ferreira ${ }^{1}$, Carlos Alberto de Carvalho Filho ${ }^{1}$, \\ Paulo César Horta Rodrigues ${ }^{1}$, Peter Marshall Fleming ${ }^{1} \&$ Luiz Cláudio Meira-Belo $^{1}$ \\ ${ }^{1}$ CDTN - Development Center of Nuclear Technology, Belo Horizonte, Brazil \\ Correspondence: Vinícius Verna Magalhães Ferreira, CDTN - Development Center of Nuclear Technology, Av. \\ Antônio Carlos 6627, Campus UFMG. CEP 31270901, Belo Horizonte, Minas Gerais, Brazil. Tel: 55-31-3069-3127. \\ E-mail: vvmf@cdtn.br
}

\author{
Received: January 13, 2012 Accepted: January 29, 2012 Online Published: April 26, 2012 \\ doi:10.5539/eer.v2n1p13 \\ URL: http://dx.doi.org/10.5539/eer.v2n1p13
}

The research is financed by INCT - National Institute of Science and Technology (Brazil).

\begin{abstract}
Mining activities generate several impacts. Besides the environmental damages, the exploration of radioactive minerals, such as uranium and thorium, is responsible for another kind of problems and concerns. Radioactive materials can remain dangerous for long time periods, what requires radioprotection measures in order to protect the health of the workers and the public in general. This work shows the results of a radiometric survey done in a uranium mine that is under a decommissioning process, in the southeast region of Brazil. The results show that there is potassium and radium in almost the whole region called Waste Rock Pile number 4, where tons of wastes are deposited. However, the radiation values are under the permissible limits for workers, although the place can not be considered as a free area, according to the Brazilian rules.
\end{abstract}

Keywords: radiation, measurements, uranium mining, decommissioning

\section{Introduction}

The first Brazilian industrial facility associated to the uranium mining activities is located in the municipality of Caldas, Minas Gerais State, and belongs to INB - Nuclear Industries of Brazil. The operation of this complex, named uranium mine Osamu Utsumi, has started in 1982. Nowadays the mining activities are ceased and the site is under the process of decommissioning. Its closure has to fulfill the legal demands of CNEN (National Commission of Nuclear Energy) and IBAMA (Brazilian Institute of the Environment and Renewable Natural Resources). The characterization of the environmental liabilities and the propositions of specific solutions for the contaminated areas due to the uranium mining activities, including acid drainage, are considered the most urgent studies to be carried out in Caldas (Nóbrega, 2007).

Mining activities generate several impacts all over the world, and the establishment of a plan to recover the degraded areas involves several researches. In order to help the development of these studies in the region of Caldas, the CDTN - Development Center of Nuclear Technology, under the scope of the INCT works (National Institute of Science and Technology) proposed to do some researches to characterize the environmental liabilities that exist in the Caldas INB unit. The project was named "Characterization and monitoring of the quality of the water and environment, and recovery of the degraded areas due to the mineral industry, including the recovery of metals from waste and industrial effluents".

This project is coordinated by the Department of Metallurgical Engineering of UFMG - Federal University of Minas Gerais, being partners the UFV - Federal University of Viçosa, the ICB/UFMG - Biological Sciences Institute of UFMG, CEFET/MG - Federal Center of Technological Education (Minas Gerais State), IIEGA International Institute of Ecology and Environmental Management, and the CDTN.

\subsection{Previous Studies}

The Plateau of Poços de Caldas was the subject of numerous studies resulting in a considerable amount of bibliographic information. The pioneer study on the geology of the Poços de Caldas Plateau was published by 
the Geological Society of London (Derby, 1887), where the first reference to the volcanic plateau can be find. From the 1930's decade, a series of works in the area began, in order to achieve a better understanding of the geology, the distribution of the mineral resources present in the Plateau, and also their economic potential. From the 50 's, great emphasis was given to prospective studies of nuclear material in the area. These studies were heavily incremented after the creation of the CNEN in 1962, whose performance in the region aiming the prospection for radioactive minerals contributed to a better knowledge of the geology of the alkaline massif. As result of these studies, radioactive anomalies were found in the "Morro do Ferro" (Iron Hill) and in the "Mina do Cercado" (Fence Mine), among others. Since then, these two places have been extensively studied. The "Morro do Ferro" was the subject of a detailed study coordinated by IAEA - International Atomic Energy Agency, due to its peculiar characteristics. The "Mina do Cercado" was transformed into the first uranium mine operated in Brazil. The task was managed by the former NUCLEBRAS (currently INB).

Since 1976, when the works began in order to characterize the place in details, to execute the mining project and to start the mining operations and the processing of uranium in the "Mina do Cercado", several complementary studies have been carried out in the region. These studies were done to characterize the hydrodynamics of the existent aquifer, to evaluate the flow direction, to verify the status of some bio indicators and to assess the natural radionuclides in the environment, among many others (Amaral, 1979; Paschoa et al., 1979; Vasconcellos et al., 1987; Prado, 1994; Campos et al., 2010).

After the closing of the "Mina do Cercado" in 1995, and the beginning of the studies to recover the degraded areas in this region, several researches have been conducted with the support of the INB. Part of these studies was done through Ph.D. thesis and M.Sc. dissertations, which evaluated several environmental components involved in the hydrogeological and hydrogeochemical characterization of the region. As example, the study of subsurface drainage of the environmental liabilities associated to the disposal of the mining waste from the "Mina do Cercado" evaluated the hydrodynamic properties of the local aquifer by drilling wells and specific tests (MDGEO, 2000). The recharge was evaluated and as a conclusion, the proposal for a groundwater flow model for the region outside the WPR4 - Waste Pile Rock number 4, was obtained and calibrated. Another important study, in the surroundings of Poços de Caldas municipality, aimed to evaluate the groundwater in their hydrogeological and hydrogeochemical aspects, with emphasis on the sources of hydrothermal waters from that city (CETEC, 1987).

The radionuclide transport at Poços de Caldas Plateau was also an object of researches (Barcellos et al., 1990; Fernandes et al., 1995), and it was showed that the tailing pond and the waste pile rock draining acid were the main sources of contamination. More recently, numerical models for simulating water flow and relevant geochemical processes in the site (Franklin, 2007) and alternatives to mitigate the impacts caused by the WPR4 (Nóbrega, 2007) were investigated in the area. Also, previous studies made a hydrogeochemical investigation of the Antas River, in order to verify the contamination in water courses downstream the mine, and the natural attenuation was considered responsible for mitigate the contamination from effluent releases in the area (Lamego et al., 2009).

\section{Objective}

The objective of this work is to show the results of a radiometric evaluation performed in the study area, measuring the gamma activity, the dose rate values and identifying the existent radionuclides, in order to verify the state of these parameters in the region, as part of the environmental researches that are being carried out. This is the first time that this kind of research is undertaken in the area, evaluating the radiation level in a sampling grid that covers all the WPR4, since the PRAD - Plan to Recover the Degraded Area, was elaborated for the site.

The study area where the radiometric survey was done is the region where the WPR4 is located, that belongs to the INB Caldas. The volume of the WPR4 is 12.4 million cubic meters, which comprehend an area of 569 thousand of square meters, situated in the ancient part of the Consulta stream (Cipriani, 2002). There are 8 Waste Pile Rocks in UTM Caldas facility, but the number 4 is the biggest one, and for this reason it was chosen to be studied. The obtained results were compared to the values of the natural radiation in the region.

\section{Study Area Characteristics}

The UTM Caldas - Ore Treatment Unit, is located in the southern region of Minas Gerais State (Figure 1), and it is approximately $180 \mathrm{~km}$ distant from the city of São Paulo, $350 \mathrm{~km}$ from Belo Horizonte and $360 \mathrm{~km}$ from the city of Rio de Janeiro (Araújo, 2005). 


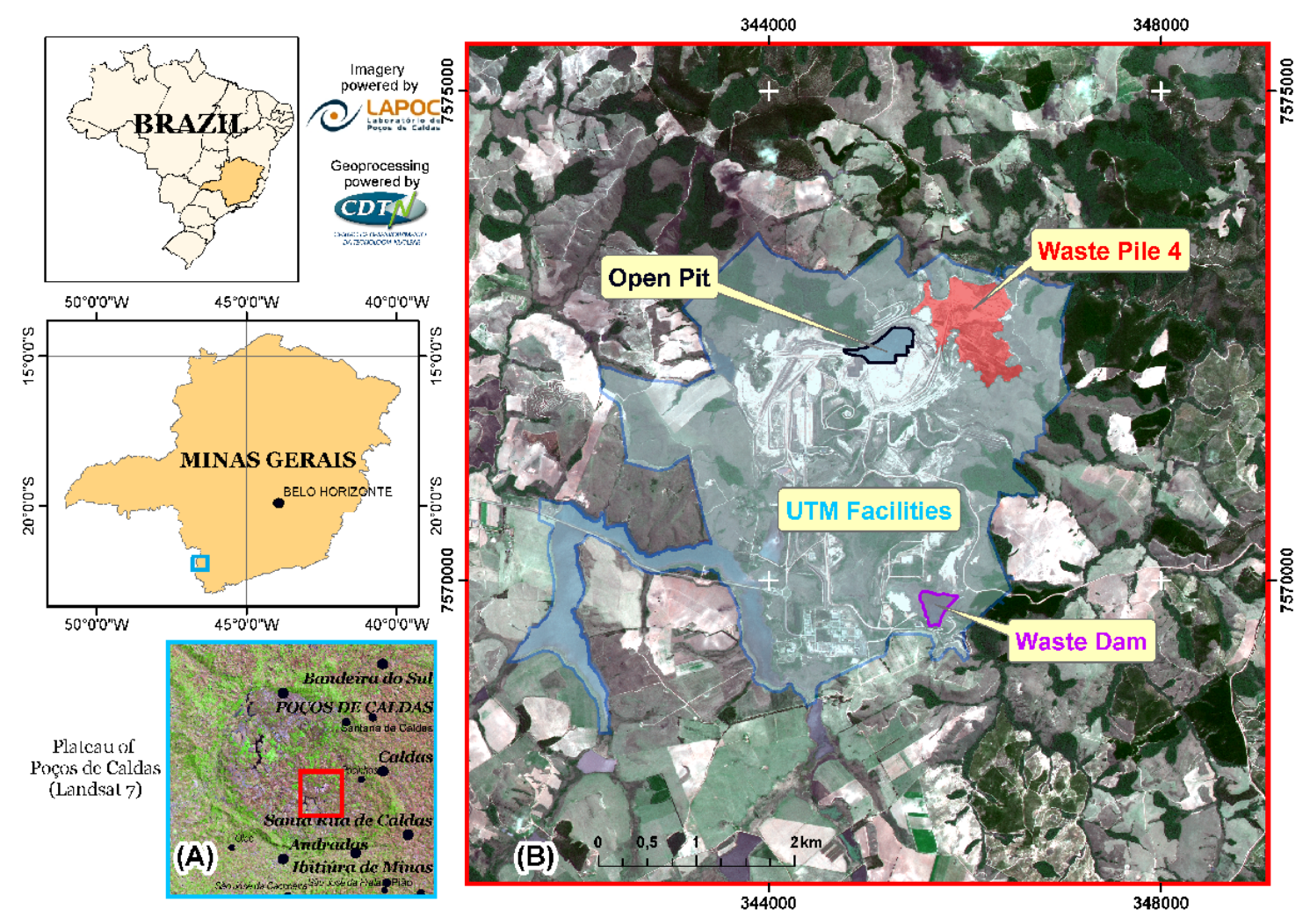

Figure 1. Location of the Caldas municipality and of the UTM

Nowadays, under the scope of the project supported by INCT, several researches are being executed in the WPR4 in order to characterize it as best as possible. Some questions related to the mine pit are under study (Figure 2), as well other important environmental aspects in the site. The main goals are to verify the level of contamination in the waters and sediments in the surrounding regions of the site, and to develop a mathematical model that can describe the hydro balance in WPR4 area (Figure 3) as well. Other studies are evaluating several questions related to the acid mine drainage and the recovery of uranium (Gomes et al., 2011; Santos \& Ladeira, 2011; Ladeira \& Gonçalves, 2008). It is expected that soon new hydrogeological studies will begin, since a new project that has technical support from the University of Queensland - Australia, was endorsed. This project will have a financial support from FAPEMIG - Research Support Foundation of Minas Gerais State.

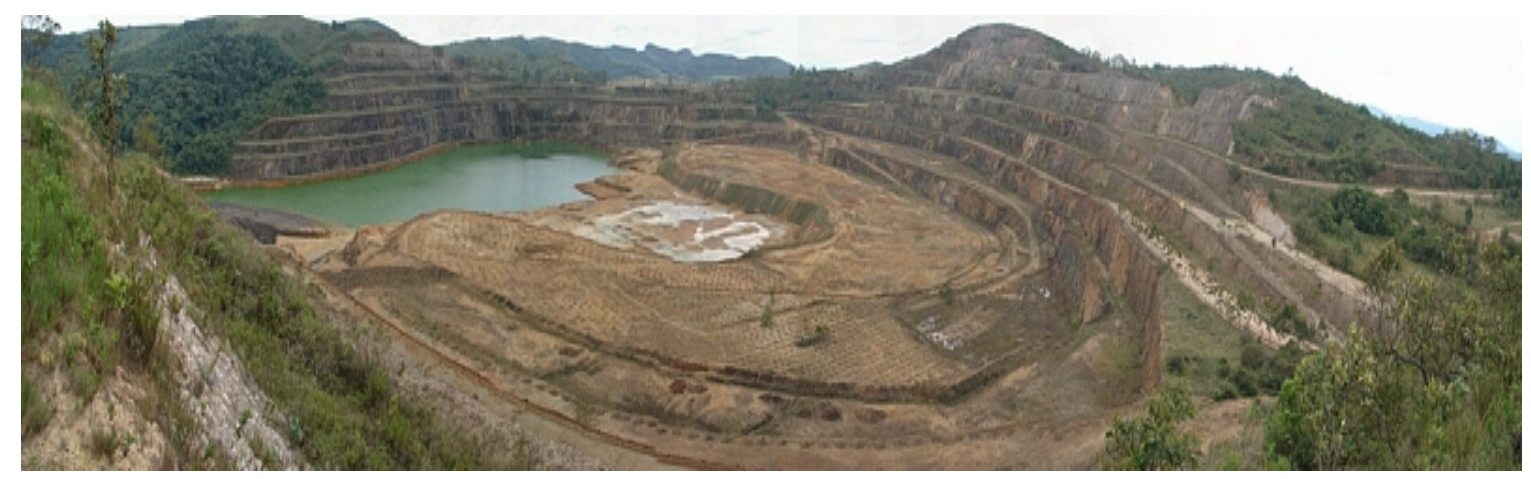

Figure 2. Mine pit - Caldas UTM 


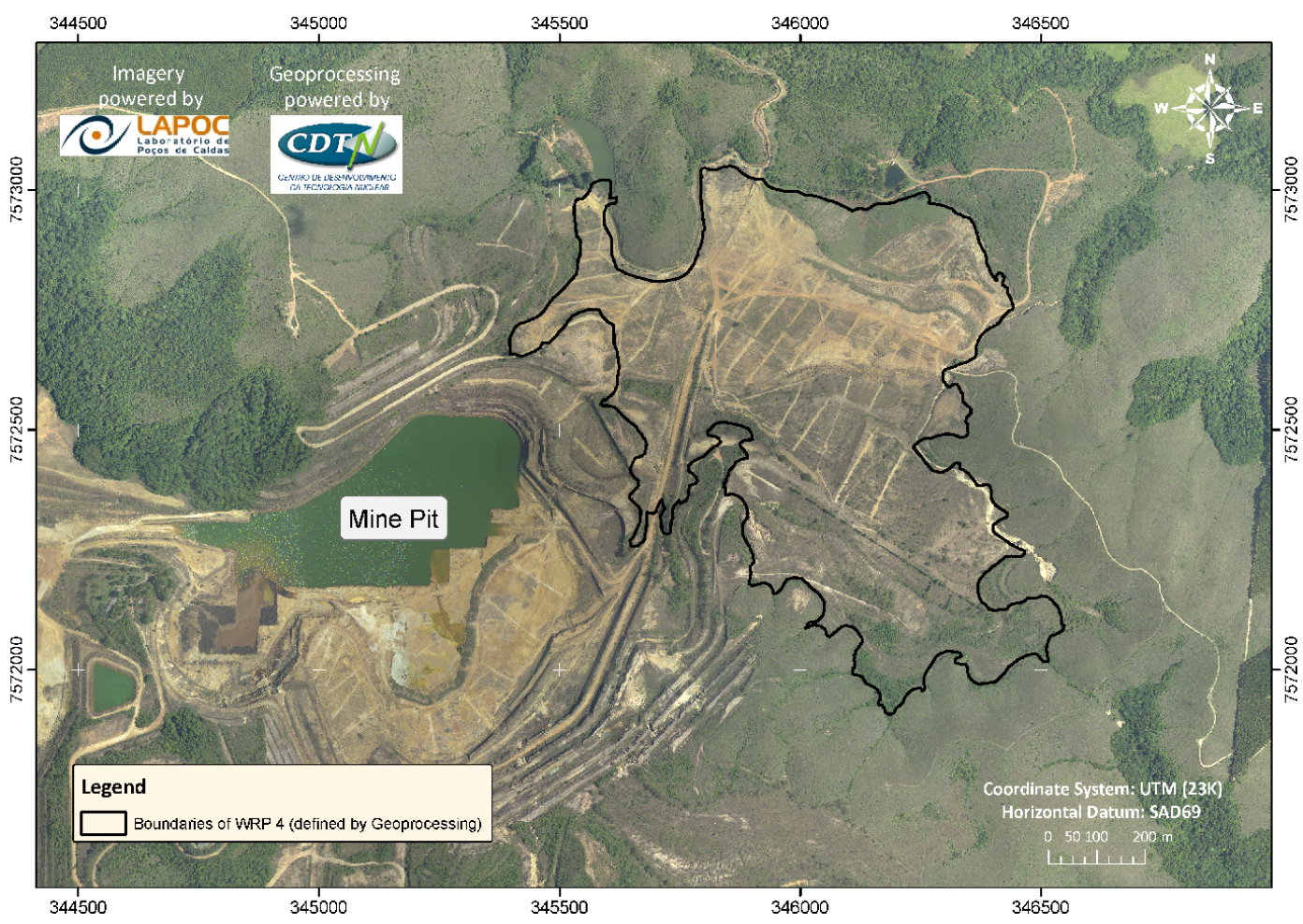

Figure 3. Boundaries of the Waste Rock Pile 4

Also, the behavior of the underground waters in the WPR4 is under study, with the help of probes and piezometers installed in four underground wells. In 2010, with the help of rain gauges, it could be verified the annual precipitation in the WPR4, and rain was registered in 142 days along the year (Figures $4 \mathrm{a}$ and $4 \mathrm{~b}$ ). The monitoring of the atmospheric pressure and temperature is underway, besides infiltration tests and the evaluation of the moisture of the soil (Figures $5 \mathrm{a}$ and $5 \mathrm{~b}$ ). It is possible to see that the temperature reaches negative values in July 2011.

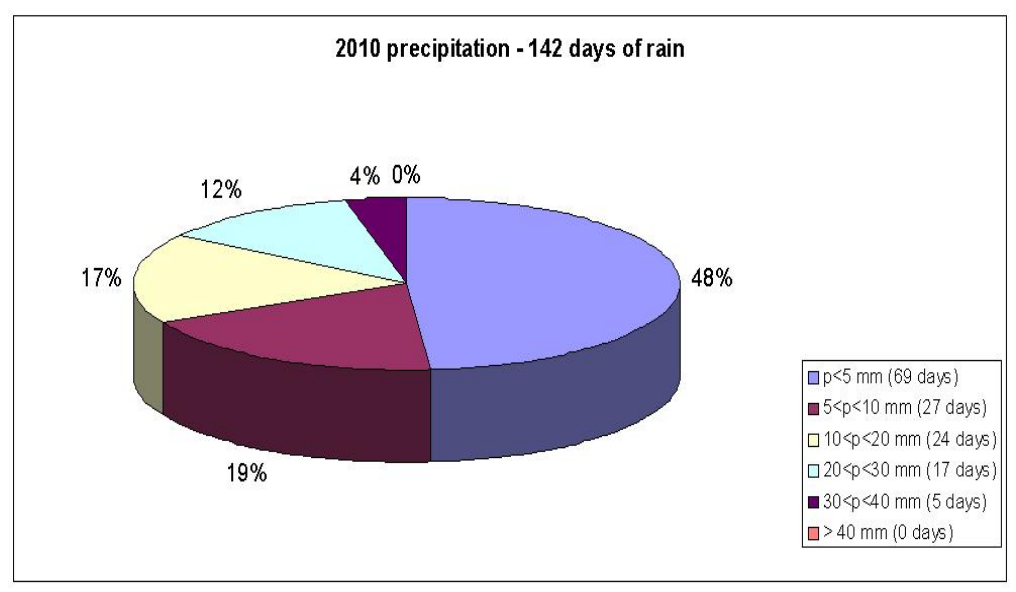

(a) 


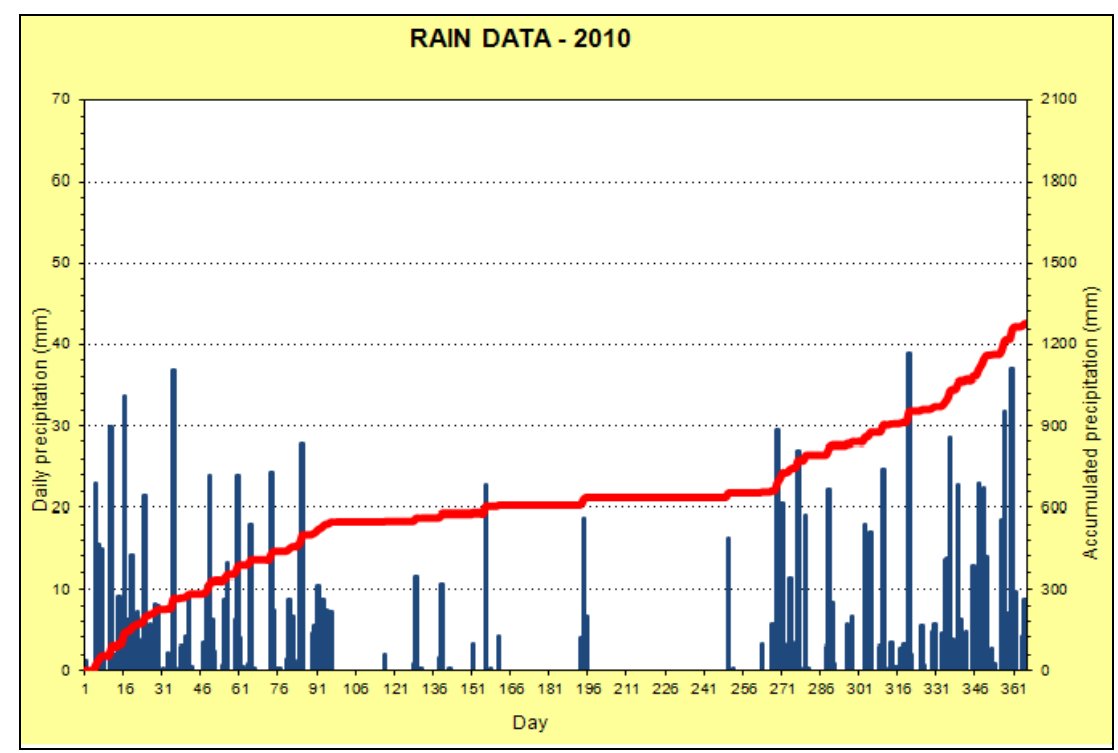

(b)

Figures 4. 2010 pluviometric data in the site under study

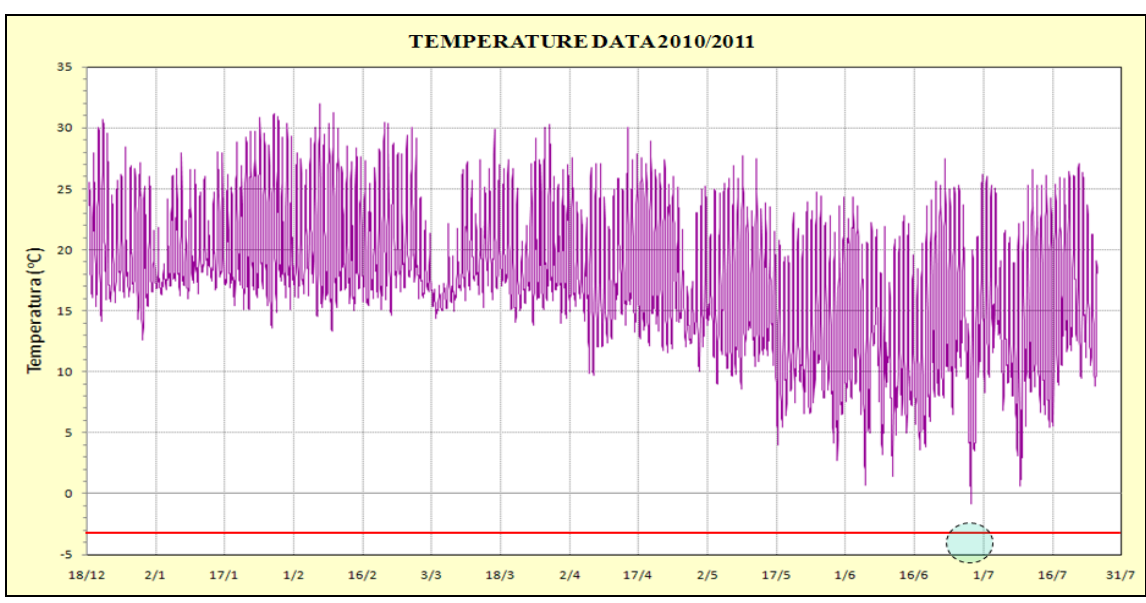

(a)

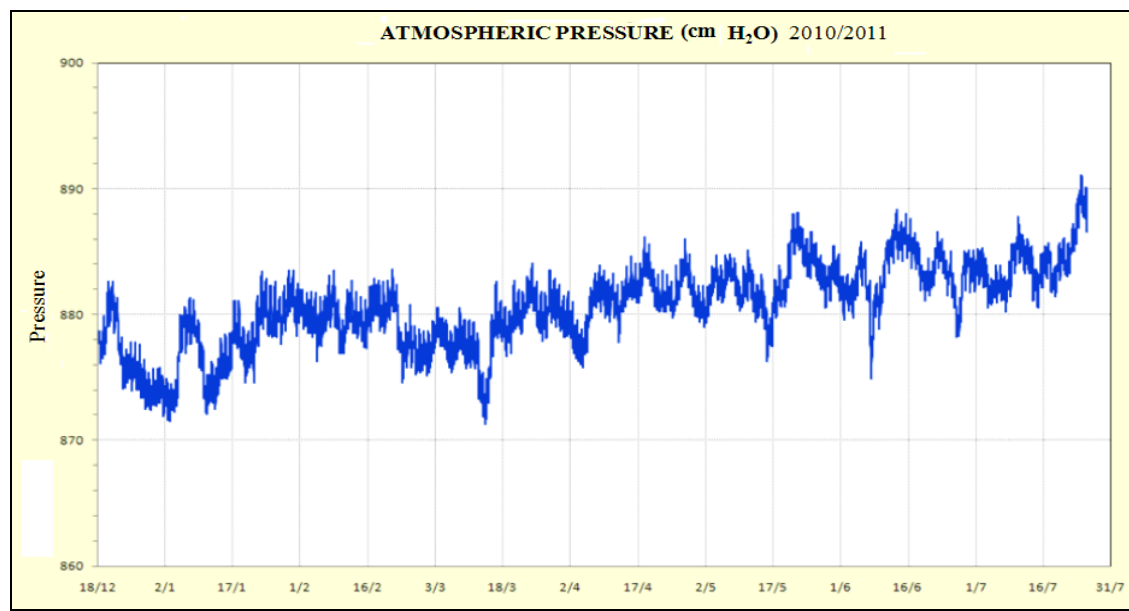

Figure 5. a) Monitoring of the temperature in the study area and

b) Monitoring of the atmospheric pressure (both from December 18, 2010 to July 31, 2011) 


\subsection{Wismut Experience}

It is worth emphasizing here that the technicians involved in the decommissioning process have the IAEA support. The project BRA 3013 has as a goal the knowledge exchanges between Brazilian and foreign technicians, aiming the implementation of a decommissioning and remediation plan for the mining and industrial complex located in Caldas. Among other benefits, this project created detailed a technical exchange with the experts from Germany that works in Wismut, including a technical visit to the place, which happened in October 2010.

WISMUT experience in remediation of uranium mining and milling legacies is considered the biggest mining rehabilitation project in the world. From 1945 to 1990, SDAG Wismut in East Germany was the major uranium supplier to the Soviet Union. Estimates indicate that approximately 216,000 tons of uranium were produced. However, during production time neither substantial technical or financial provisions were made for closure of mining and decommissioning process. Immediately following unification of Germany, the WISMUT mining operations were discontinued and a fund of approximately 6.2 billion of Euros was provided for the clean-up and remediation of the environmental liabilities in the uranium mining areas (IAEA, 2005).

After a preliminary survey, the remediation focused on five mining sites (Ronneburg, Aue, Pöhla, Königstein \& Gittersee) and two processing sites (Seelingstädt \& Crossen). The main tasks to be done were the demolition of contaminated buildings and structures, the cleaning of the area and to solve several questions associated to the waste rock piles, industrial tailings ponds, underground and open pit mines and water treatment (Hagen \& Jakubic, 2006), (Czegka et al., 2006). The scope of the closure program was vast and included 5 underground mines, $37 \mathrm{~km}^{2}$ of operational areas including 2 milling sites and $311 \mathrm{M} \mathrm{m}^{3}$ of 20,000 tons of uranium deposited in 48 waste rock piles, among other tasks (Hagen, 2007).

\section{Methodology}

To assess a radiometric evaluation of the study area, a sampling grid was defined for the region. Part of the original net used and installed by the LAPOC - Laboratory of the National Commission of Nuclear Energy in Poços de Caldas, for studies related to the detection of radon gas through passive detectors, was adopted (Macacini, 2008). The grid of the original study was defined in a range of $25 \times 25$ meters, however due to operational reasons in this activity, the working area was redefined as a $50 \times 25$ meters grid. Once that the net was defined, in each sampling point the geographical coordinates, the temperature, the gamma radiation rate (CPS - Counts Per Second), the dose rate ( $\mu$ Sv per hour) and gases samples were obtained/collected. The procedure was made following the recommendations of a technical document of IAEA (IAEA, 2003), which cover all aspects of the uranium mining industry, from exploration to exploitation, decommissioning, and the application of techniques in other non-uranium resources areas.

The measurements were done using a portable gamma spectrometer IdentiFINDER model XYZ, which carries out qualitative and quantitative analysis of gamma radiation using a $\mathrm{NaI}(\mathrm{Tl})$ detector and an internal Geiger Mueller (GM) tube. On very high dose rates (above $500 \mu \mathrm{Sv} / \mathrm{h}$ ), the scintillation detector is switched off and the GM tube is responsible for the dose rate display. The initial calibration and, furthermore, the permanent and continuous stabilization running in the background in parallel to any performed measurement, are based on an internal Cs-137 stabilization source. It is valid to observe that in this work, the device had to be turned on outside the research area, due to the existent natural radiation, since the presence of strong sources may disturb the stabilization and calibration of the IdentiFINDER. A precise energy calibration though is essential for the identification of any nuclides found in the field.

After the drilling of the soil in order to collect the gases as part of environmental studies (Abreu et al., 2011), the radiation measurement was done with the device touching the soil surface. The procedure was done in sequence, covering all the sampling points in the study area. The soil temperature was also checked (this parameter was used in the gases analyses). It is valid to emphasize that the device must be pointed to the source of radiation. If the acquisition time is too short or the radiation level is too low, the identification algorithm does not start. The instrument was programmed to detect only one or two radionuclides, in order to optimize its performance. The IdentiFINDER has a trust level in the measurement that goes from zero (what means unlikely) to ten - very likely. A very weak indication is displayed as "-". This trust level represents the capacity of the device to identify correctly the spectrum of the radionuclides.

ISO 18589-1 (ISO, 2005) provides guidance for measurements of radionuclides in the soil, including the studies made for decommissioning purposes. It defines general procedures of gamma spectrometry measurement, and requirements for measurements of radioactivity in the soil. ISO recommends that sampling must be representative of the area under investigation, what was followed since the measurements were done in the 
whole WPR4 area using, as indicated, a portable radioactivity detector that can identify individual radionuclides. The limits of the IdentiFINDER go from $0.01 \mu \mathrm{Sv} / \mathrm{h}$ up to $1 \mathrm{~Sv} / \mathrm{h}$, what answer to the ISO needed requirements. It is valid to emphasize here that the CDTN emitted a calibration certificate for the IdentiFINDER (CDTN, 2009), where the error in all measurements was declared as 5\% for the range of its operation in WPR4. For bigger values the uncertainties order reaches $8 \%$.

Figure 6 shows the sampling net in the region of study. The field works were performed in June and July of 2010 .

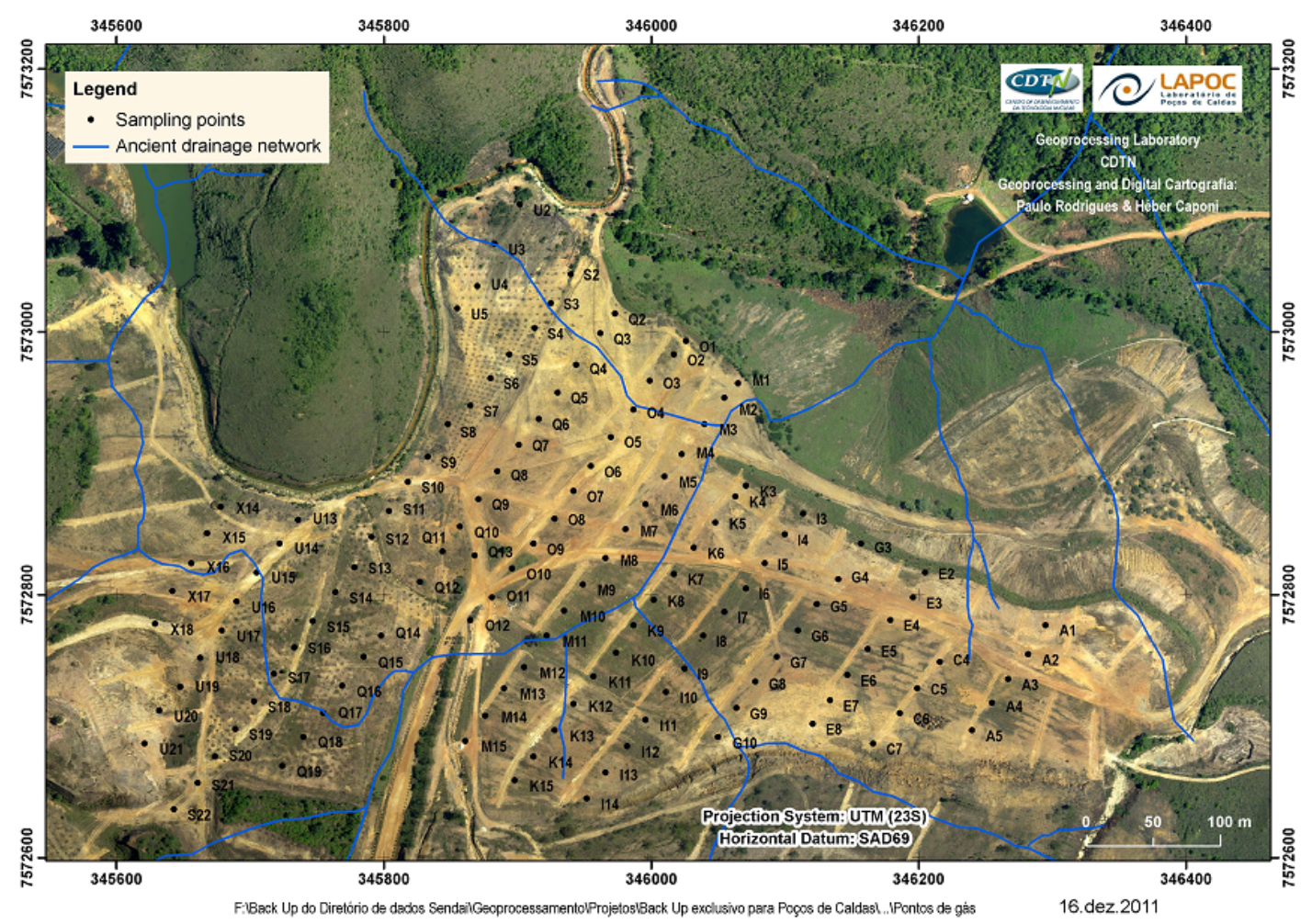

Figure 6. Sampling net used in the study

\section{Results and Discussion}

Table 1 shows some results of the evaluations done in the study area.

Table 1. Results of the measurements

\begin{tabular}{cccccccccccc}
\hline $\begin{array}{c}\text { Point } \\
\text { Code }\end{array}$ & $\begin{array}{c}\text { Dose } \\
\text { Rate } \\
\boldsymbol{\mu S v} / \mathbf{h}\end{array}$ & CPS & $\begin{array}{c}\text { Radio } \\
\text { nuclide 1 }\end{array}$ & $\begin{array}{c}\text { Trust } \\
\text { level }\end{array}$ & $\begin{array}{c}\text { Radio } \\
\text { nuclide 2 }\end{array}$ & $\begin{array}{c}\text { Trust } \\
\text { level }\end{array}$ & $\begin{array}{c}\text { Point } \\
\text { Code }\end{array}$ & $\begin{array}{c}\text { Dose } \\
\text { Rate } \\
\boldsymbol{\mu S v} / \mathbf{h}\end{array}$ & CPS & $\begin{array}{c}\text { Radio } \\
\text { nuclide 1 }\end{array}$ & $\begin{array}{c}\text { Trust } \\
\text { level }\end{array}$ \\
\hline A1 & 1.35 & 1540 & Ra 226 & 5 & - & - & K15 & 1.27 & 1533 & Ra 226 & 6 \\
A2 & 1.26 & 1494 & Ra 226 & 5 & - & - & KSW & 1.48 & 1693 & Ra 226 & 7 \\
A3 & 0.94 & 1162 & Ra 226 & 5 & - & - & M15 & 1.46 & 1717 & Ra 226 & 6 \\
A4 & 0.86 & 1082 & Ra 226 & 5 & - & - & M1 & 1.00 & 1156 & - & - \\
A5 & 1.08 & 1312 & Ra 226 & 6 & - & - & M2 & 1.00 & 1175 & - & - \\
ASW & 1.90 & 2040 & Ra 226 & 6 & K40 & 4 & M3 & 1.76 & 1835 & Ra 226 & 6 \\
B0 & 0.89 & 1213 & Ra 226 & 5 & - & - & M4 & 1.21 & 1431 & Ra 226 & 4 \\
B1 & 1.52 & 1812 & Ra 226 & 6 & - & - & M6 & 0.95 & 1281 & - & - \\
\hline
\end{tabular}




\begin{tabular}{|c|c|c|c|c|c|c|c|c|c|c|c|}
\hline $\begin{array}{l}\text { Point } \\
\text { Code }\end{array}$ & $\begin{array}{c}\text { Dose } \\
\text { Rate } \\
\mu \text { Sv/h }\end{array}$ & CPS & $\begin{array}{c}\text { Radio } \\
\text { nuclide } 1\end{array}$ & $\begin{array}{l}\text { Trust } \\
\text { level }\end{array}$ & $\begin{array}{c}\text { Radio } \\
\text { nuclide } 2\end{array}$ & $\begin{array}{l}\text { Trust } \\
\text { level }\end{array}$ & $\begin{array}{l}\text { Point } \\
\text { Code }\end{array}$ & $\begin{array}{c}\text { Dose } \\
\text { Rate } \\
\mu \mathrm{Sv} / \mathrm{h} \\
\end{array}$ & CPS & $\begin{array}{c}\text { Radio } \\
\text { nuclide } 1\end{array}$ & $\begin{array}{l}\text { Trust } \\
\text { level }\end{array}$ \\
\hline B2 & 1.38 & 1725 & $\operatorname{Ra} 226$ & 5 & - & - & M7 & 1.05 & 1237 & $\operatorname{Ra} 226$ & 4 \\
\hline B3 & 0.89 & 1103 & Ra 226 & 5 & K40 & 4 & M8 & 2.26 & 2462 & $\mathrm{Ra} 226$ & 8 \\
\hline B4 & 0.89 & 1195 & Ra 226 & 4 & - & - & M9 & 0.91 & 1183 & $\mathrm{Ra} 226$ & 4 \\
\hline B5 & 0.78 & 1096 & Ra 226 & 5 & - & - & M10 & 0.89 & 1142 & - & - \\
\hline $\mathrm{C} 4$ & 1.32 & 1581 & Ra 226 & 5 & - & - & M12 & 0.80 & 1079 & - & - \\
\hline $\mathrm{C} 5$ & 0.88 & 1141 & Ra 226 & 5 & - & - & M13 & 0.90 & 1160 & - & - \\
\hline C6 & 1.04 & 1305 & Ra 226 & 4 & - & - & M14 & 0.93 & 1200 & - & - \\
\hline $\mathrm{C} 7$ & 1.60 & 1810 & $\mathrm{Ra} 226$ & 6 & - & & $\mathrm{O} 1$ & 1.00 & 1170 & $\mathrm{Ra} 226$ & 4 \\
\hline CSW & 1.70 & 1845 & Ra 226 & 5 & K40 & 4 & $\mathrm{O} 2$ & 0.62 & 834 & - & - \\
\hline D2 & 1.14 & 1390 & $\mathrm{Ra} 226$ & 4 & - & - & $\mathrm{O} 3$ & 1.15 & 1390 & - & - \\
\hline D3 & 0.96 & 1270 & $\mathrm{Ra} 226$ & 4 & - & - & $\mathrm{O} 4$ & 1.80 & 1970 & $\mathrm{Ra} 226$ & 6 \\
\hline D4 & 1.48 & 1680 & $\mathrm{Ra} 226$ & 7 & - & - & O5 & 1.56 & 1703 & $\mathrm{Ra} 226$ & 6 \\
\hline D5 & 0.70 & 930 & $\mathrm{Ra} 226$ & 4 & - & - & O6 & 1.24 & 1433 & Ra 226 & 4 \\
\hline E2 & 0.55 & 756 & - & - & - & - & O7 & 1.42 & 1620 & $\mathrm{Ra} 226$ & 4 \\
\hline E3 & 0.83 & 1030 & - & - & - & - & O8 & 1.27 & 1477 & - & - \\
\hline E4 & 1.71 & 1865 & $\mathrm{Ra} 226$ & 5 & - & - & O9 & 1.32 & 1504 & $\mathrm{Ra} 226$ & 5 \\
\hline E5 & 0.91 & 1153 & - & - & - & - & $\mathrm{O} 10$ & 0.43 & 718 & - & - \\
\hline E6 & 0.90 & 1114 & $\mathrm{Ra} 226$ & 1 & - & - & O11 & 1.21 & 1440 & - & - \\
\hline E7 & 1.75 & 1943 & $\operatorname{Ra} 226$ & 7 & - & - & $\mathrm{O} 12$ & 0.97 & 1203 & - & - \\
\hline E8 & 1.43 & 1661 & $\mathrm{Ra} 226$ & 4 & - & - & Q2 & 2.12 & 2280 & Ra 226 & 6 \\
\hline ESW & 1.95 & 2179 & $\mathrm{Ra} 226$ & 7 & - & - & Q3 & 2.72 & 2990 & Ra 226 & 7 \\
\hline F3 & 1.37 & 1520 & $\mathrm{Ra} 226$ & 6 & - & - & Q4 & 1.48 & 1670 & $\mathrm{Ra} 226$ & 5 \\
\hline F4 & 1.61 & 1800 & $\mathrm{Ra} 226$ & 7 & - & - & Q5 & 1.53 & 1727 & Ra 226 & 5 \\
\hline F5 & 0.86 & 1160 & $\mathrm{Ra} 226$ & 6 & - & - & Q6 & 1.10 & 1266 & $\mathrm{Ra} 226$ & 4 \\
\hline G3 & 0.53 & 762 & - & - & - & - & Q8 & 1.13 & 1320 & $\mathrm{Ra} 226$ & 5 \\
\hline G4 & 0.83 & 1032 & - & - & - & - & Q9 & 1.30 & 1544 & $\mathrm{Ra} 226$ & 5 \\
\hline G5 & 0.91 & 1121 & $\mathrm{Ra} 226$ & 4 & - & - & Q10 & 2.21 & 2458 & $\mathrm{Ra} 226$ & 7 \\
\hline G6 & 0.75 & 1000 & $\mathrm{Ra} 226$ & 5 & - & - & Q11 & 1.28 & 1560 & $\mathrm{Ra} 226$ & 5 \\
\hline G7 & 0.91 & 1105 & - & - & - & - & Q12 & 1.23 & 1458 & - & - \\
\hline G8 & 0.97 & 1188 & - & - & - & - & Q14 & 1.02 & 1220 & Ra 226 & 5 \\
\hline G9 & 1.12 & 1300 & - & - & - & - & Q15 & 0.78 & 995 & - & - \\
\hline G10 & 1.18 & 1373 & $\mathrm{Ra} 226$ & 6 & - & - & Q16 & 0.79 & 1014 & - & - \\
\hline GSW & 1.33 & 1462 & $\mathrm{Ra} 226$ & 4 & K40 & 1 & Q17 & 1.00 & 1260 & - & - \\
\hline X14 & 1.36 & 1618 & $\mathrm{Ra} 226$ & 4 & K 40 & 1 & Q18 & 1.26 & 1447 & $\mathrm{Ra} 226$ & 6 \\
\hline $\mathrm{X} 18$ & 1.41 & 1652 & $\mathrm{Ra} 226$ & 6 & K 40 & 1 & Q19 & 1.21 & 1430 & $\mathrm{Ra} 226$ & 6 \\
\hline ISW & 1.30 & 1417 & $\mathrm{Ra} 226$ & 4 & K 40 & 1 & S3 & 2.03 & 2278 & $\mathrm{Ra} 226$ & 4 \\
\hline $\mathrm{H} 4$ & 0.87 & 1205 & $\mathrm{Ra} 226$ & 5 & - & - & S4 & 2.25 & 2376 & $\mathrm{Ra} 226$ & 7 \\
\hline $\mathrm{I} 3$ & 0.67 & 852 & $\mathrm{Ra} 226$ & 5 & - & - & S5 & 1.54 & 1777 & $\mathrm{Ra} 226$ & 7 \\
\hline I4 & 0.88 & 1086 & - & - & - & - & S6 & 1.05 & 1263 & Ra 226 & 6 \\
\hline I5 & 0.82 & 1013 & $\mathrm{Ra} 226$ & 5 & - & - & S9 & 1.89 & 2085 & $\mathrm{Ra} 226$ & 5 \\
\hline I6 & 0.88 & 1081 & $\mathrm{Ra} 226$ & 4 & - & - & S10 & 1.51 & 1695 & $\mathrm{Ra} 226$ & 6 \\
\hline I7 & 0.74 & 981 & $\mathrm{Ra} 226$ & 4 & - & - & S11 & 1.33 & 1545 & $\mathrm{Ra} 226$ & 5 \\
\hline
\end{tabular}




\begin{tabular}{|c|c|c|c|c|c|c|c|c|c|c|c|}
\hline $\begin{array}{l}\text { Point } \\
\text { Code }\end{array}$ & $\begin{array}{c}\text { Dose } \\
\text { Rate } \\
\mu S v / h\end{array}$ & CPS & $\begin{array}{c}\text { Radio } \\
\text { nuclide } 1\end{array}$ & $\begin{array}{l}\text { Trust } \\
\text { level }\end{array}$ & $\begin{array}{c}\text { Radio } \\
\text { nuclide } 2\end{array}$ & $\begin{array}{l}\text { Trust } \\
\text { level }\end{array}$ & $\begin{array}{l}\text { Point } \\
\text { Code }\end{array}$ & $\begin{array}{c}\text { Dose } \\
\text { Rate } \\
\mu \mathrm{Sv} / \mathbf{h}\end{array}$ & CPS & $\begin{array}{c}\text { Radio } \\
\text { nuclide } 1\end{array}$ & $\begin{array}{l}\text { Trust } \\
\text { level }\end{array}$ \\
\hline I8 & 0.69 & 915 & $\operatorname{Ra} 226$ & 1 & - & - & S12 & 1.38 & 1540 & $\operatorname{Ra} 226$ & 1 \\
\hline I9 & 0.76 & 1031 & - & - & - & - & S13 & 1.14 & 1362 & Ra 226 & 1 \\
\hline $\mathrm{I} 10$ & 1.54 & 1778 & $\operatorname{Ra} 226$ & 5 & - & - & S14 & 0.94 & 1210 & $\mathrm{Ra} 226$ & 5 \\
\hline I11 & 1.03 & 1254 & Ra 226 & 4 & $\mathrm{Pu} 240$ & 0 & S15 & 0.74 & 1017 & - & - \\
\hline $\mathrm{I} 12$ & 1.30 & 1526 & Ra 226 & 5 & - & - & S16 & 0.78 & 1020 & Ra 226 & 1 \\
\hline I13 & 1.07 & 1291 & Ra 226 & 5 & - & - & S17 & 1.16 & 1420 & Ra 226 & 6 \\
\hline I14 & 1.05 & 1282 & $\mathrm{Ra} 226$ & 6 & - & - & S18 & 1.05 & 1301 & - & - \\
\hline $\mathrm{J} 0$ & 0.80 & 1103 & $\mathrm{Ra} 226$ & 5 & - & - & S19 & 1.41 & 1590 & Ra 226 & 6 \\
\hline $\mathrm{J} 1$ & 0.84 & 1066 & $\mathrm{Ra} 226$ & 5 & - & - & S20 & 1.04 & 1258 & Ra 226 & 5 \\
\hline $\mathrm{J} 2$ & 0.99 & 1312 & $\mathrm{Ra} 226$ & 5 & - & - & S21 & 1.49 & 1638 & Ra 226 & 8 \\
\hline $\mathrm{J} 3$ & 1.22 & 1566 & $\operatorname{Ra} 226$ & 6 & - & - & S22 & 1.18 & 1307 & $\operatorname{Ra} 226$ & 5 \\
\hline $\mathrm{J} 4$ & 0.65 & 920 & $\operatorname{Ra} 226$ & 4 & - & - & U2 & 0.76 & 971 & $\operatorname{Ra} 226$ & 4 \\
\hline K3 & 0.82 & 972 & $\mathrm{Ra} 226$ & 6 & - & - & U3 & 0.72 & 928 & - & - \\
\hline K4 & 1.38 & 1617 & Ra 226 & 7 & - & - & U4 & 1.52 & 1704 & Ra 226 & 6 \\
\hline K5 & 1.00 & 1243 & $\operatorname{Ra} 226$ & 1 & - & - & U5 & 2.32 & 2533 & Ra 226 & 7 \\
\hline K6 & 0.94 & 1150 & $\mathrm{Ra} 226$ & 1 & - & - & U13 & 1.62 & 1859 & Ra 226 & 5 \\
\hline K7 & 0.92 & 1128 & $\mathrm{Ra} 226$ & 4 & - & - & U14 & 1.76 & 1962 & Ra 226 & 7 \\
\hline K8 & 1.01 & 1224 & $\mathrm{Ra} 226$ & 5 & - & - & U15 & 1.62 & 1860 & - & - \\
\hline K9 & 0.83 & 1080 & $\operatorname{Ra} 226$ & 5 & - & - & U16 & 1.36 & 1633 & Ra 226 & 5 \\
\hline K10 & 0.91 & 1114 & $\mathrm{Ra} 226$ & 5 & - & - & U17 & 1.50 & 1675 & Ra 226 & 6 \\
\hline K11 & 0.88 & 1101 & - & - & - & - & U18 & 2.08 & 2325 & Ra 226 & 7 \\
\hline K12 & 1.08 & 1300 & - & - & - & - & U19 & 0.77 & 950 & - & - \\
\hline K13 & 1.00 & 1203 & - & - & - & - & U20 & 0.75 & 975 & - & - \\
\hline K14 & 0.87 & 1102 & Ra 226 & 4 & - & - & U21 & 0.81 & 1022 & - & - \\
\hline M5 & 1.30 & 1441 & $\mathrm{Ra} 226$ & 7 & K40 & 1 & $\mathrm{X} 15$ & 1.18 & 1408 & Ra 226 & 5 \\
\hline M11 & 0.87 & 1135 & Ra 226 & 5 & $\mathrm{Pu} 240$ & 0 & X16 & 1.28 & 1538 & Ra 226 & 6 \\
\hline $\mathrm{MCA}$ & 1.30 & 1517 & $\mathrm{Ra} 226$ & 6 & K40 & 1 & $\mathrm{X} 17$ & 1.24 & 1560 & - & - \\
\hline Q7 & 1.28 & 1472 & $\operatorname{Ra} 226$ & 5 & K 40 & 1 & Y0 & 1.54 & 1823 & Ra 226 & 5 \\
\hline Q130 & 1.00 & 1188 & $\mathrm{Ra} 226$ & 5 & $\mathrm{Pu} 240$ & 1 & $\mathrm{Y} 1$ & 0.76 & 987 & Ra 226 & 4 \\
\hline S2 & 1.73 & 1920 & $\operatorname{Ra} 226$ & 5 & K 40 & 1 & Y2 & 0.63 & 912 & $\mathrm{Ra} 226$ & 4 \\
\hline S7 & 1.20 & 1400 & Ra 226 & 5 & K 40 & 1 & $\mathrm{Y} 3$ & 1.01 & 1212 & Ra 226 & 5 \\
\hline S8 & 1.09 & 1275 & $\mathrm{Ra} 226$ & 6 & K 40 & 1 & Y4 & 1.55 & 1912 & Ra 226 & 5 \\
\hline $\mathrm{H} 1$ & 0.71 & 964 & $\mathrm{Ra} 226$ & 5 & - & - & $\mathrm{Z1}$ & 0.95 & 1201 & $\mathrm{Ra} 226$ & 5 \\
\hline $\mathrm{H} 2$ & 1.20 & 1504 & $\mathrm{Ra} 226$ & 5 & - & - & $\mathrm{Z} 2$ & 0.66 & 912 & Ra 226 & 5 \\
\hline $\mathrm{H} 3$ & 0.88 & 1221 & $\mathrm{Ra} 226$ & 0 & - & - & & & & & \\
\hline
\end{tabular}

It is possible to see that ${ }^{226} \mathrm{Ra}$ was found in $77.5 \%$ of the points where the values were measured, and in some points the trust level of the device reaches 8 . Potassium 40 and ${ }^{240} \mathrm{Pu}$ were found in less than $1 \%$ of the points, however the trust level indicates that is not likely the presence of these two nuclides.

A statistical analysis was performed considering all the measurements presented in Table 1, with the help of the MINITAB 16 software. The results show that only four points are considered as outliers: M8, Q3, Q10 and U5 (Figure 7), and all of them are located at the northwestern part of the WPR4. The gamma radiation and the dose rate distribution curves have the same aspect, as expected (Figure 8). 

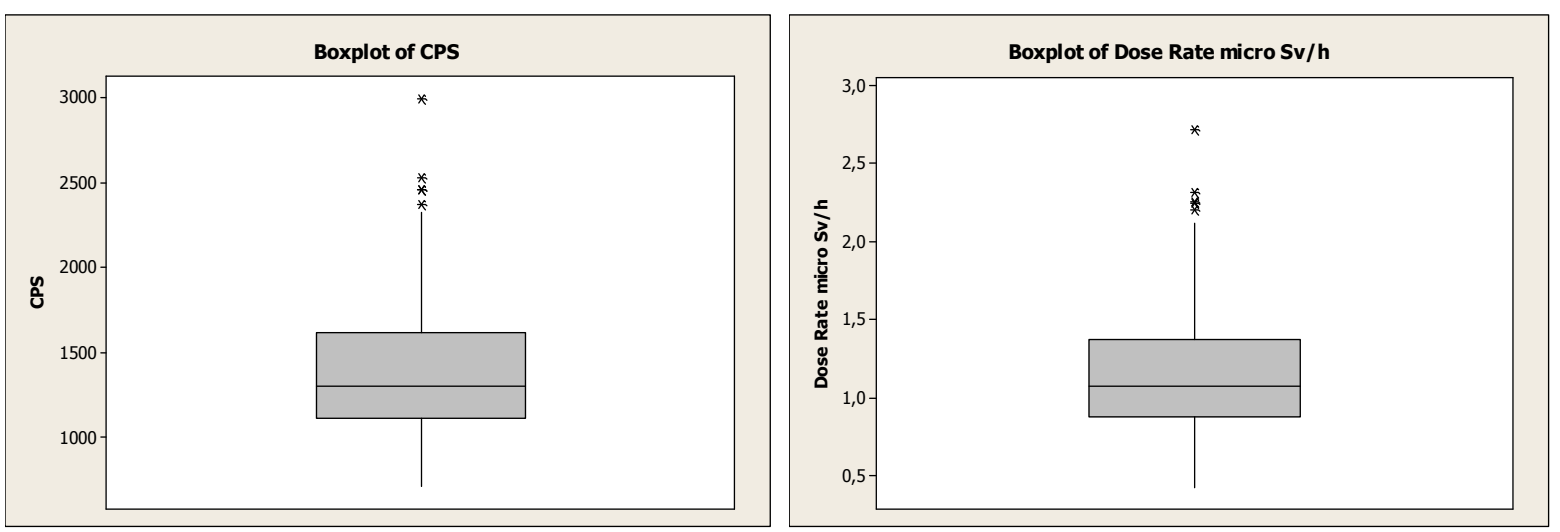

Figure 7. Boxplots of CPS and dose rate
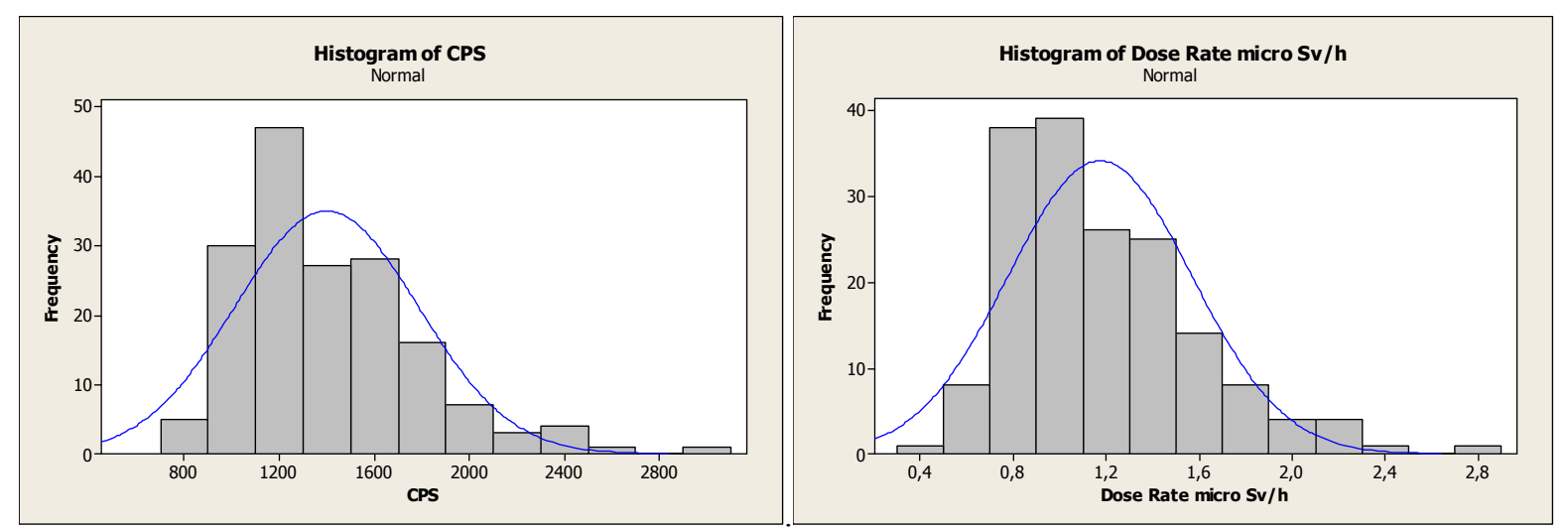

Figure 8. Histogram (normal distribution) for CPS and dose rate

Figures 9 and 10 show the obtained results for gamma activity and dose rates. It is possible to observe the existence of a central zone going from NE to SW where the gamma activity rate (and also the dose rate) is relatively smaller, probably due to the presence, in a significant amount, of a allochthonous clay-like material that was deposited in the surface of the waste pile in order to act as a barrier to prevent the infiltration of rainwater.

Table 2 shows some results of the statistical analysis for the counts per second and for the dose rate.

Table 2. Statistical analysis (normal distribution)

\begin{tabular}{lcc}
\hline Parameter & Dose rate $(\mu \mathbf{S v} / \mathbf{h})$ & Counts per second \\
\hline Mean & 1.17 & 1398.8 \\
SD - Standard Deviation & 0.40 & 386.1 \\
Minimum value & 0.43 & 718.0 \\
1 st quartile & 0.88 & 1117.5 \\
Median & 1.08 & 1301.0 \\
3rd quartil & 1.38 & 1619.0 \\
Maximum value & 2.72 & 2990.0 \\
95\% interval confidence for mean & $1.11-1.23$ & $1340.2-1457.4$ \\
95\% interval confidence for median & $1.00-1.20$ & $1246.2-1419.1$ \\
95\% interval confidence for SD & $0.35-0.44$ & $348.9-432.3$ \\
\hline
\end{tabular}




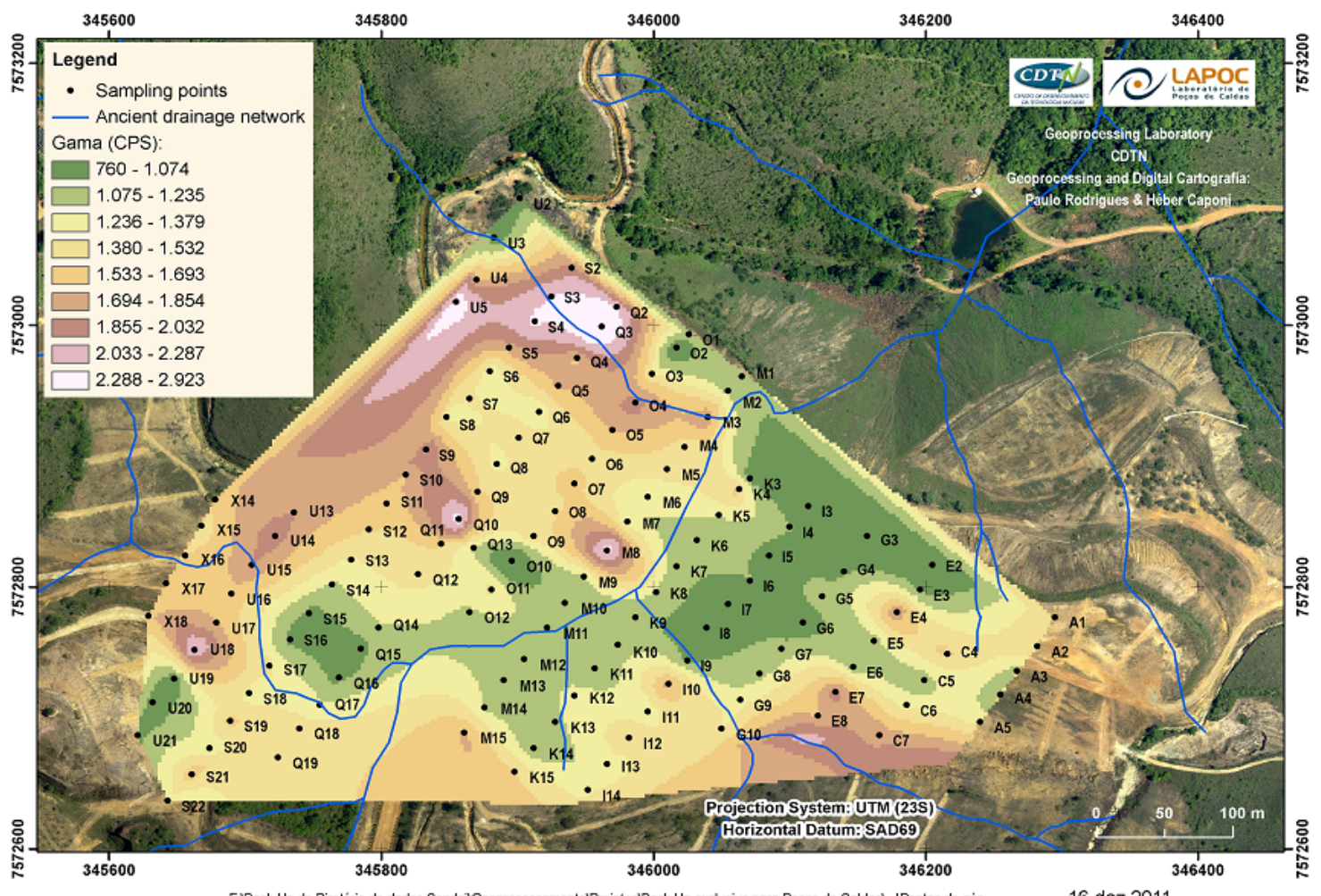

Figure 9. Spatial distribution of the gamma activity rates (CPS)

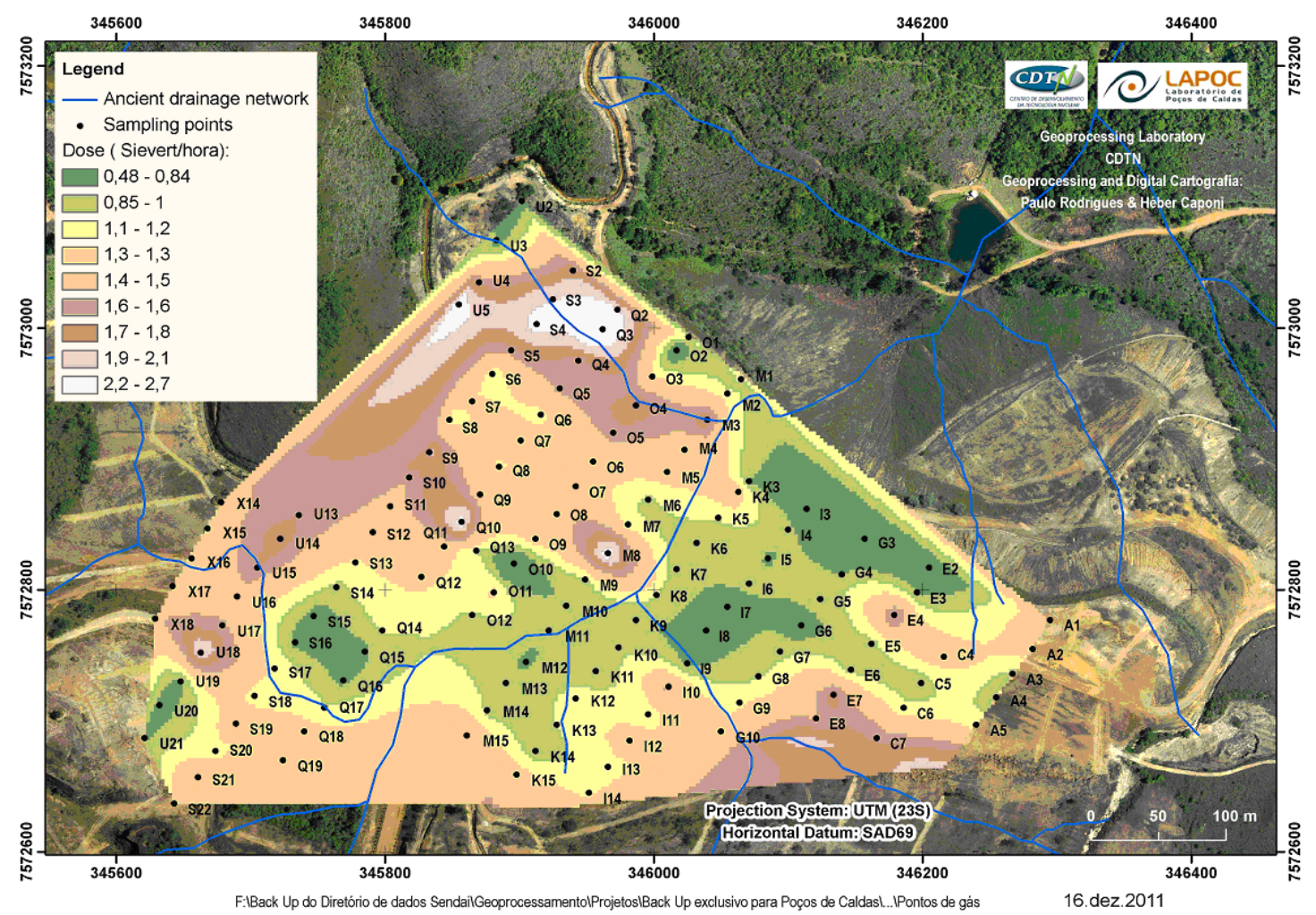

Figure 10. Spatial distribution of the dose rates values 
According to CNEN rules (CNEN, 2005), the limit dose established for workers is $20 \mathrm{mSv} / \mathrm{year}$ which corresponds to a dose rate of approximately $2.28 \mu \mathrm{Sv} / \mathrm{h}$. In this study 169 points were analyzed, and only in two of them the dose rate measured had a higher value than the limit: Q3 $(2.72 \mu \mathrm{Sv} / \mathrm{h})$ and U5 $(2.32 \mu \mathrm{Sv} / \mathrm{h})$.

A pre operational environmental survey performed in 1978/1980 in the region of Poços de Caldas plateau measured the natural radiation, and the average value found was $0,22 \mu \mathrm{Sv} / \mathrm{h}$ (Amaral et al., 1984). Considering this value as the natural background of the plateau, and subtracting it from the measured values, only the point Q3 remains above the limit dose established for workers. Thus, according to this work, the study site, although practically all free for workers, is not a free area for the public, since the limit established for the public in free areas, according to the national rules, is $1 \mathrm{mSv} /$ year $(0,14 \mu \mathrm{Sv} / \mathrm{h})$. It is worth emphasizing that the values considered were measured at ground level and at the entrance of the holes. This configuration provides information on dose in extremities (feet in this case) and not dose of whole body, although the values used to refer to measures of whole body. So, the obtained values are conservative in favor of the safety of the individual. In addition, the shielding effect due to the layer of soil on the radioactive material was removed, highlighting the effect of the presence of radionuclide in the deeper layers of soil.

UNSCEAR (2000) considers a classification of radioactive areas according to the average effective dose of the natural radiation:

- $\quad$ less than $5 \mathrm{mSv} / \mathrm{year}=$ normal values;

- $\quad$ between 5 and $20 \mathrm{mSv} / \mathrm{year}=$ medium values;

- $\quad$ between 20 and $50 \mathrm{mSv} / \mathrm{year}=$ high values;

- $\quad$ higher than $50 \mathrm{mSv} / \mathrm{year}=$ very high values.

Thus, according to this classification, it is possible to see that the values (Table 1), except for Q3 and U5, are considered medium or normal. Nevertheless, in the "Mina do Ferro" area, the values found in previous researches are very high (Table 3), and the radiation levels are above the safety limits. However, this is a rural area with almost none inhabitants.

Table 3. Measurements of the natural radiation in the uranium mine surrounding cities (SES/MG, 2009)

\begin{tabular}{lcccccc}
\hline Municipality & Area/zone & $\begin{array}{c}\text { Arithmetical } \\
\text { average dosis } \\
\text { (mSv/year) }\end{array}$ & $\begin{array}{c}\text { Number } \\
\text { of points }\end{array}$ & $\begin{array}{c}\text { Minimum } \\
\text { value } \\
\text { (mSv/year) }\end{array}$ & $\begin{array}{c}\text { Maximum } \\
\text { value } \\
\text { (mSv/year) }\end{array}$ & $\begin{array}{c}\text { Average dosis } \\
\text { weighted by } \\
\text { population } \\
\text { (mSv/year) }\end{array}$ \\
\hline Andradas & Municipality & 0.59 & 93,645 & 0.19 & 8.60 & 0.54 \\
& Urban area & 0.54 & 21,413 & 0.19 & 1.33 & 0.54 \\
Caldas & Rural area & 0.61 & 72,125 & 0.19 & 8.60 & 0.53 \\
& Municipality & 0.70 & 113,349 & 0.13 & 14.43 & 0.66 \\
Ibitiúra de & Urban area & 0.75 & 8363 & 0.30 & 4.13 & 0.71 \\
Minas & Municipality & 0.55 & 14,119 & 0.23 & 1.96 & 0.59 \\
& Urban area & 0.70 & 2810 & 0.34 & 1.65 & 0.62 \\
Poços de & Rural area & 0.52 & 11,493 & 0.23 & 1.96 & 0.69 \\
Caldas & Municipality & 1.03 & 109,854 & 0.15 & 95.05 & 0.51 \\
& Urban area & 0.98 & 62,363 & 030 & 3.74 & 0.98 \\
Santa Rita de & Municipality & 0.69 & 105,692 & 0.13 & 14.43 & 0.98 \\
Caldas & Urban area & 0.64 & 5781 & 0.26 & 1.26 & 0.85 \\
& Rural area & 0.47 & 73,041 & 0.09 & 1.70 & 0.57 \\
& & & & & & 0.64 \\
\hline
\end{tabular}


It is valid to observe here that from 2004 to 2009, a survey was done in five municipalities that are close to the region of study: Poços de Caldas, Andradas, Caldas, Ibitiúra de Minas and Santa Rita de Caldas. The objective of this research was to measure the natural radiation that exists in the area, aiming to verify if the levels represented a danger to the population, since this situation can be found in some countries, as Sudan, where a dose of $38.4 \mathrm{mSv} /$ year was measured and in India, where previous studies found $31.4 \mathrm{mSv} / \mathrm{year}$ (Hendry, 2009). The survey was performed in an area of $230.187 \mathrm{~km}^{2}$, and the measurements were done in 409.257 points. However, the values found showed that the cities under study do not present high values, as expected for a region where the environmental radioactive level is high, and the same conclusion was obtained in other studies (Sachett, 2002).

According to another studies done in Brazil, the natural radiation that exists in the surrounding cities of the uranium mine is not much higher than those ones from other parts of the country. Table 4 shows some results of these measurements (SES-MG, 2009).

Table 4. Measurements of natural radiation in some brazilian municipalities (SES/MG, 2009)

\begin{tabular}{lcc}
\hline \multicolumn{1}{c}{ Studied area } & $\begin{array}{c}\text { Number of } \\
\text { points }\end{array}$ & (mSv/year) \\
\hline São Paulo capital- 43 health districts in the municipality & 118 & 0.75 \\
Rio de Janeiro capital - (preserved lands, part of Recreio dos Bandeirantes & 4268 & 0.65 \\
neighborhood) & & \\
Águas da Prata - São Paulo State (15 urban areas) & 848 & 0.65 \\
Guarapari - Espirito Santo State (24 urban areas) & 9815 & 0.73 \\
Andradas - Minas Gerais State (10 urban areas) & 3546 & 0.61 \\
Caldas - Minas Gerais State (urban area) & 345 & 0.80 \\
Poços de Caldas - Minas Gerais State (15 urban areas) & 7189 & 0.89 \\
Poços de Caldas - Minas Gerais State (urban area) & 7189 & 0.91 \\
\hline
\end{tabular}

\section{Conclusions}

The decommissioning of UTM/INB Caldas is a task that challenges all the professionals involved in the project since this is the first time that this kind of task is done in Brazil. To quantify and evaluate to damages created by the mining activity is not a simple problem, but efforts are being done to assess the contamination in the waters and sediments in the surrounding regions of the INB site.

This work showed the preliminary net that was chosen to analyze the WPR-4 area, and it was possible to verify that there is Ra-226 in the whole area. Also, K-40 was found in several points were the measurements were done. In some places $\mathrm{Pu}-240$ was found, but according to the trust level, this result should be not considered as reliable. The radiation levels found show that the study site can not be considered as a free area.

The environmental liabilities existent in the study area should be carefully evaluated and quantified, since the nuclear area is always seen as a sector that does not show transparency in its actions and procedures. The local community should be informed of all the tasks that are being executed. Public acceptance and participation is a vital key for the success of all the questions related to the nuclear sector.

\section{Acknowledgments}

The authors thank the INCT, FAPEMIG and CNPq support, and the other colleagues involved in the project tasks. Also, the INB collaboration was vital for the development of the activities, as well the activities of Dr. Alexandre Oliveira (LAPOC), coordinator of the project BRA 3013.

\section{References}

Abreu, C. B., Fleming, P. M., Ciminelli, V. S. T., Rodrigues, P. C. H., Lopez, D. L., \& Branco, O. E. A. (2011). Soil gas compositions as a tool for understanding acid mine drainage formation and air flow in a uranium waste rock pile. 11th Congress of the IMWA - International Mine Water Association - Mine Water Managing the Challenges. (pp. 247-252). Aachen, Germany. ISBN 978-1-897009-47-5. 
Amaral, E. C. S. (1979). Comportamento do Ra 226 no ambiente aquático da região da mina de urânio, Poços de Caldas, MG. Dissertation (Master's degree in Biological Sciences) - Biophysics Institute, Federal University of Rio de Janeiro, Brazil.

Amaral, E. C. S., Azevedo, H. L. P., \& Mendonça, A. H. (1985). Pre operational environmental survey at the uranium mine and mill site, Poços de Caldas, Minas Gerais, Brasil. The Science of the Total Environment, 42(3), 257-266. http://dx.doi.org/10.1016/0048-9697(85)90061-0

Araújo, V. P. (2005). Análise crítica do sistema de gerenciamento de rejeitos provenientes de mineração e beneficiamento de urânio - um estudo de caso da unidade de concentrado de urânio/INB. Dissertation (Master's degree in Radioprotection and Dosimetry), Radioprotection and Dosimetry Institute - National Commission of Nuclear Energy, Rio de Janeiro - RJ, Brazil.

Barcelos, C. C., Amaral, E., \& Rochedo, E. (1990). Radionuclide transport by Poços de Caldas Plateau Rivers, Brazil. Environmental Technology, 11(6). 533-540. http://dx.doi.org/10.1080/09593339009384894

Campos, M. B., Azevedo, H., Nascimento, M. R. L., Roque, C. V., \& Rodgher, S. (2010). Environmental assessment of water from a uranium mine (Caldas, Minas Gerais State, Brazil) in a decommissioning operation. Environmental Earth Sciences, 62(4), 857-863. http://dx.doi.org/10.1007/s12665-010-0572-9

CDTN - Development Center of Nuclear Energy. (2009). Certificado de calibração 5544/CDTN/09. Serviço de dosimetria das radiações. Laboratório de calibração de dosímetros. Belo Horizonte - Brazil.

CETEC - Technological Center of Minas Gerais. (1987). Avaliação Hidrogeológica e Hidroquímica dos Arredores de Poços de Caldas - Belo Horizonte. Technical Report. 137 pages. Belo Horizonte - Brazil.

CNEN - National Commission of Nuclear Energy. (2005). NN-3.01 Basic Guidelines for Radiological Protection. Rio de Janeiro - Brazil. Retrieved from http://www.cnen.gov.br/seguranca/normas/mostra-norma.asp?op=301 (January 28, 2012).

Cipriani, M. (2002). Mitigação dos impactos sociais e ambientais decorrentes do fechamento definitivo de minas de urânio. Ph.D. Thesis (Doctor's degree in Geosciences - Administration and Mineral Resources Policies), State University of Campinas, SP - Brazil.

Czegka, W., Hanisch, C., Junge, F., Zerling, L., \& Baborowski, M. (2006). Changes in Uranium concentration in the Weisse Elster River as a mirror of the remediation in the former WISMUT mining area. Uranium in the Environment. (1st ed.). Heidelberg, Germany: Springer Link. 875-884. http://dx.doi.org/10.1007/3-540-28367-6_91

Derby, O. A. (1887). On nepheline rocks in Brazil, with special reference to the association of phonolite and foyaite. Quarterly Journal of the Geological Society of London, 43, 457-473. http://dx.doi.org/10.1144/GSL.JGS.1887.043.01-04.35

Fernandes, H. M., Veiga, L. H. S., Franklin, M. R., Prado, V. C. S., \& Taddei, J. F. (1995). Environmental impact assessment of uranium mining and milling facilities: a study case at the Poços de Caldas uranium mining and milling site, Brazil. Journal of Geochemical Exploration, 52(1-2), 161-173. http://dx.doi.org/10.1016/0375-6742(94)00043-B

Franklin, M. R. (2007). Modelagem numérica do escoamento hidrológico e dos processos geoquímicos aplicados à previsão da drenagem ácida em uma pilha de estéril da mina de urânio de Poços de Caldas - MG. Ph. D. Thesis (Doctor's degree in Sciences: Civil Engineering). Federal University of Rio de Janeiro, Brazil.

Gomes, A. F. S., Lopez, D. L., \& Ladeira, A. C. Q. (2011). Characterization and assessment of chemical modifications of metal-bearing sludges arising from unsuitable disposal. Journal of Hazardous Materials, 199-200, 418-425. http://dx.doi.org/10.1016/j.jhazmat.2011.11.039

Hagen, M. (2007). The Wismut Uranium Mining Rehabilitation Project Running for 15 Years - Lessons Learned and Achievements. Advanced Materials Research, 20-21(Biohydrometallurgy: From the Single Cell to the Environment), 243-247. http://dx.doi.org/10.4028/www.scientific.net/AMR.20-21.243

Hagen, M., \& Jakubick, A. (2006). Returning the WISMUT legacy to productive use. Uranium in the Environment. (1st ed.). Heidelberg, Germany: Springer Link. 11-26. http://dx.doi.org/10.1007/3-540-28367-6_2

Hendry, J. H., Simon, S. L., Wojcik, A., Sohrabi, M., Burkant, W., Cardis, E., ...Hayata, I. (2009). Human exposure to high natural background radiation: what can it teach us about radiation risks? Journal of Radiological Protection, 29(2A), 29-42. http://dx.doi.org/10.1088/0952-4746/29/2A/S03 
IAEA - International Atomic Energy Agency. TECDOC-1363. (2003). Guidelines for radioelement mapping using gamma ray spectrometry data. Vienna, Austria. Retrieved from http://www-pub.iaea.org/mtcd/publications/pdf/te_1363_web.pdf (January 29, 2012).

IAEA - International Atomic Energy Agency. TECDOC-1463. (2005). Recent developments in uranium exploration, production and environmental issues. Proceedings of a technical meeting organized by the IAEA in cooperation with the OECD Nuclear Energy Agency and DIAMO State Owned Enterprise held in Straz, $\quad$ Czech $\quad$ Republic, 6-8 September. $\quad$ Retrieved from http://www-pub.iaea.org/MTCD/Publications/PDF/te_1463_web.pdf (January 28, 2012).

IdentiFINDER User's manual. (2005). Target Systemelectronic gmbh. Germany.

ISO - International Organization for Standardization. (2005). 18589-1 Measurement of radioactivity in the environment-soil. Part 1: general guidelines and definitions. Switzerland.

Ladeira, A. C. Q., \& Gonçalves, C. R. (2008). Uranium recovery and manganese removal from acid mine drainage. WIT (Wessex Institute of Technology) Transactions on Ecology and the Environment, 111, WP080451. http://dx.doi.org/10.2495/WP080451

Lamego, F., Lauria, D., Vasconcellos, L., Clain, A. F., Scassioti Filho, W., Antunes, I., \& Nascimento, M. (2009). Hydrogeochemistry of Antas River, Poços de Caldas (MG, Brazil). XII Brazilian Congress of Geochemistry. Ouro Preto - MG, Brazil.

Macacini, J. F. (2008). Desenvolvimento de método para quantificação de taxa de exalação de $222 \mathrm{Rn}$ em bacia de rejeitos radioativos e estudo de solo como material mitigador. Ph. D. Thesis (Doctor's degree in Sciences) - Center of Nuclear Energy in Agriculture, São Paulo University, SP - Brazil.

MDGEO Hydrogeological Services Ltda. (2000). Inventário dos pontos de água no entorno da Mina Osamu Utsumi e demais instalações das Indústrias Nucleares do Brasil S/A. Technical Report, 78 pages.

Nóbrega, F. A. (2007). Análise de Múltiplas Variáveis no Fechamento de Minas - Estudo de Caso da Pilha de Estéril BF-4, Mina Osamu Itsumi, INB Caldas, Minas Gerais. Dissertation (Master's degree in Mineral Engineering), Federal University of Ouro Preto, MG - Brazil.

Paschoa, A. S., Baptista, G. B., \& Montenegro, E. C. (1979). Ra-226 concentrations in the hydrographic basins near uranium mining and milling in Brazil. Low-level radioactive waste management. Health physics society twelfth midyear topical symposium (pp. 337-350). Williamsburg, Virginia, USA.

Prado, V. C. S. (1994). O impacto da produção de concentrado de urânio sobre a qualidade da água dos rios Um estudo de caso na área do Complexo Mínero Industrial do Planalto de Poços de Caldas. Dissertation (Master's Degree in Sciences, Nuclear Engineering and Energy Planning). Federal University of Rio de Janeiro - Brazil.

Sachett, I. A. (2002). Caracterização da radiação gama ambiental em áreas urbanas utilizando uma unidade móvel de rastreamento. Ph.D. thesis (Doctor's degree in Biology) - Rio de Janeiro State University, Rio de Janeiro - Brazil.

Santos, E. A., \& Ladeira, A. C. Q. (2011). Recovery of Uranium from Mine Waste by Leaching with Carbonate-Based Reagents. Environmental Science \& Technology, 45, 3591-3597. http://pubs.acs.org/doi/abs/10.1021/es2002056

SES-MG - Health State Secretary of Minas Gerais State. (2009). Project Poços de Caldas Plateau: Research cancer and natural radiation. Technical Report. 112 pages. Belo Horizonte - Brazil. Retrieved from http://www.cnen.gov.br/lapoc/Projeto_pocos_de_caldas.pdf (January 31, 2012).

UNSCEAR - United Nations Scientific Committee on the Effects of Atomic Radiation (2000). Sources and effects of ionizing radiation. United Nations Scientific Committee on the effects of atomic radiation. Report to the General Assembly. Vol. I. Sources. Annex B - Exposures from natural radiation sources.

Vasconcellos, L. M. H., Amaral, E. C. S., \& Vianna, M. E. (1987). Uptake of ${ }^{226} \mathrm{Ra}$ and ${ }^{210} \mathrm{~Pb}$ by food crops cultivation in a region of high natural radioactivity in Brazil. Journal of Environmental Radioactivity, 5(4), 287-302. http://dx.doi.org/10.1016/0265-931X(87)90004-X 